7. Тихвинский В.О., А. Б. Юрчук, С. В. Терентьев . Сети мобильной связи LTE: технологии и архитектура. - М.: Эко-Трендз, 2010. - 284 с.

\title{
Сапыжанов T.A.
}

Ғылыми жетекші: Бахтиярова Е.А.

Ұялы байланыс сапасын бағалау әдістерін салыстырмалы талдау

Андатпа. Мақалада ұялы байланыс қызметтерінің әртүрлі әдістері мен негізгі параметрлері берілген. Байланыс сапасын және одан әрі жетілдіруді талдаудың негізгі талаптары мен критерийлері келтірілген.

Кілт сөздер: әдістеме, модель, сапаны бағалау, сөйлеу сапасы.

\section{Sapyzhanov T.A.}

Scientific superviser: Bakhtiyarova Ye.A.

\section{Comparative analysis of mobile quality assessment methodologies}

Abstract. The article presents various methods and basic parameters of mobile communication services. The basic requirements and criteria for quality analysis and further improvement are given.

Key words: methodology, model, quality assessment, speech quality.

\section{Сведения об авторах:}

Сапыжанов Темірлан Анварұлы, магистрант, 2 курс, специальность 6М071900 «Радиотехника, электроника и телекоммуникации».

Бахтиярова Елена Ажибековна, к.т.н., ассистент-профессор кафедры «Радиотехника, электроника и телекоммуникации» Международного университета информационных технологий.

УДК 621.398

Данабекова М.Б., Сағынтай Г.Е.

Международный университет информационных технологий

Алматы, Казахстан

Научный руководитель: Айтмагамбетов А.3.

\section{ПЛАТФОРМА ИНТЕРНЕТА ВЕЩЕЙ ДЛЯ МОНИТОРИНГА ОКРУЖАЮЩЕЙ СРЕДЫ}

\begin{abstract}
Аннотация: В этой статье представлен способ создания платформы IоT, состоящий из беспроводных сенсорных узлов на основе устройств Arduino, шлюза Raspberry Pi, который обеспечивает сетевое подключение для сенсорных узлов, и сетевых приложений, использующихся для сбора данных и их визуального представления конечному пользователю через веб-интерфейс или мобильное приложение.
\end{abstract}

Ключевые слова: технология LPWAN, LoRaWAN, Arduino, Raspberry Pi.

\section{Введение}

Технология LoRaWAN использовалась для подключения сенсорных узлов к облачному приложению благодаря ряду преимуществ, таких как дальность связи и энергопотребление по сравнению с конкурентными технологиями. Сегодня существует множество различных 
технологии, такие как ZigBee, WiFi, LTE, LoRaWAN используемых для контроля качества воздуха.Рост Интернета вещей усилит тенденцию развития этих технологий [1].

\section{Технология LoRaWAN}

LoRaWAN - это технология LPWAN, основанная на принципе кодирования сигналов LoRa. Этот принцип кодирования сигнала основан на технологии расширенного спектра, и связь включена по нескольким каналам с различными коэффициентами расширения. Он оптимизирован для передачи небольших объемов данных со скоростью от 0,3 кбит/с до 50 кбит/c. LoRa обеспечивает адаптивную скорость передачи данных и выходную мощность передатчика.

Основными характеристиками этой технологии являются:

- способность работать на больших расстояниях между устройствами, поэтому радиус действия устройств в городских условиях колеблется от 2 до 5 км и около 15 км в сельской местности в условиях оптической видимости;

- низкое энергопотребление, при котором одно конечное устройство может работать месяцами, даже годами, питаясь от одного элемента батареи;

- очень высокий уровень безопасности, так как полная связь обеспечивается от начала до конца с использованием шифрования AES-128.

Устройства LoRaWAN работают в нелицензированных областях радиочастотного спектра ISM (промышленность, наука и медицина). Пользователям разрешено работать на частотах 433 МГц, 868 МГц и 915 МГц, что регулируется нормативными актами в зависимости от региона. Скорость передачи данных зависит от выбранной ширины полосы и коэффициента расширения, а также ширина полосы канала может составлять 125 кГц, 250 кГц или 500 кГц.

\section{Узлы и шлюз}

Клиентские узлы основаны на:

- Платформе Arduino Pro Mini;

- датчиках для измерения физических величин;

- приемопередатчиках RFM95 [4].

RFM95 - это приемопередатчик, который обеспечивает сверхдальнюю связь и высокую устойчивость к помехам. Он характеризуется очень низким энергопотреблением, небольшими размерами и широким диапазоном связи, что делает его чрезвычайно подходящим для использования в сенсорных сетях с батарейным питанием. На рисунке 1 показан RFM95, схема подключения приемопередающего модуля RFM95 и Arduino Uno (R3). Модуль имеет встроенный датчик температуры, низкоуровневый детектор батареи, c корого можно считывать уровень принимаемого сигнала (RSSI) и отношение сигнал / шум (SNR). Связь с микроконтроллером достигается с помощью интерфейса SPI в полудуплексном режиме. Arduino Uno является ведущим устройством, а приемопередающий модуль RFM95 является ведомым устройством.

Центральным узлом сети LoRaWAN является коммуникационный шлюз [5]. Его основными функциями являются обеспечение передачи данных между узлами датчика и приложением. Шлюз в этом проекте основан на компьютере Raspberry Pi 3 и радиомодуле IMST iC880a. Этот модуль имеет возможность декодировать до 8 независимых потоков данных одновременно без их влияния друг на друга. Дальность связи этого шлюза составляет несколько км в городской местности и до 15 км в сельской местности. 


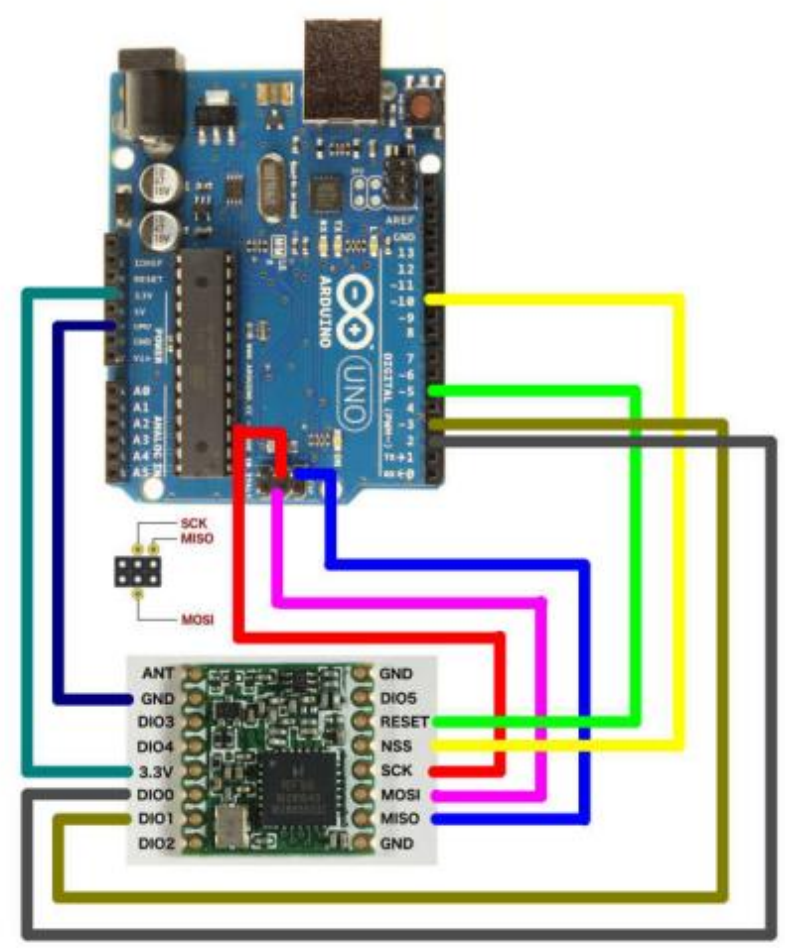

Рисунок 1 - Схема подключения приемопередатчика RFM95

\section{Реализованная сенсорная сеть}

На рисунке 2 показана реализованная архитектура сенсорной сети. Сенсорные узлы получают данные о: температуре воздуха, атмосферном давлении, влажности воздуха, качестве воздуха, уровне освещенности и уровне ультрафиолетового излучения. Эти датчики выбраны в первую очередь потому, что они непосредственно применимы к большому количеству пользователей и позволяют нам отслеживать параметры окружающей среды, но любой другой датчик может быть легко реализован с использованием соответствующей библиотеки программного обеспечения. В этом проекте мы используем следующие датчики:

- Bosch BMP 280 для измерения температуры, атмосферного давления и высоты;

- ВН1750 для измерения внешнего освещения;

- AM2302 (DHT22) для измерения влажности и температуры воздуха.

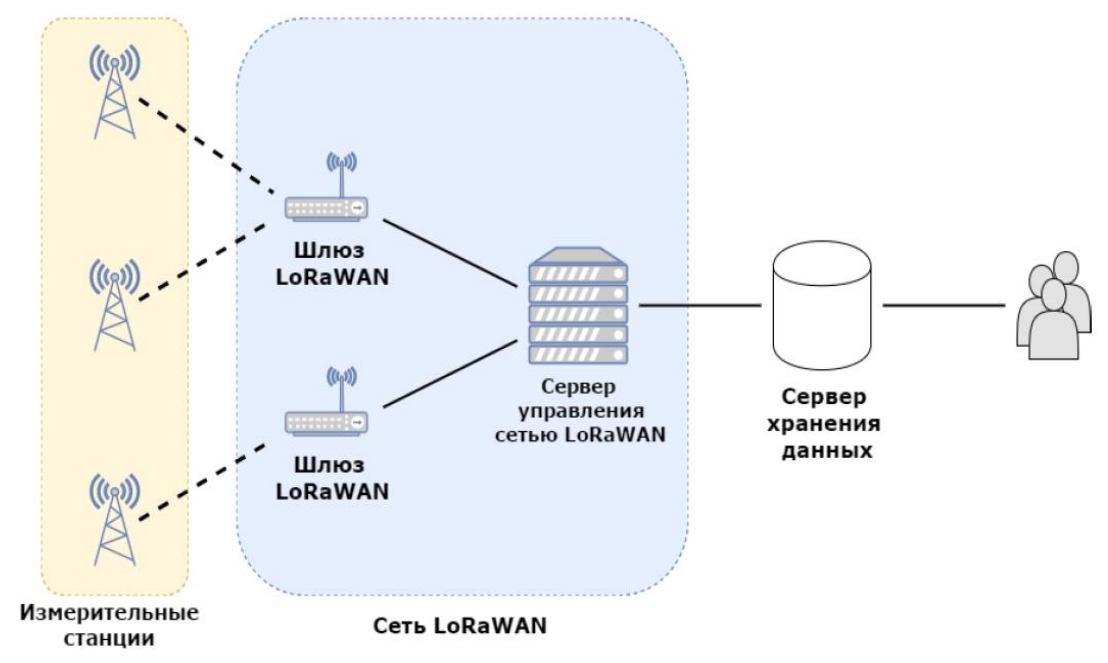

Рисунок 2 - Реализованная сети передачи данных LoRa

International Journal of Information and Communication Technologies, Vol.1, Issue 1, March, 2020 
Сторонние приложения получают данные о состоянии окружающей среды с сервера обработки и хранения данных, приводят их в соответствие с принятыми в регионе единицами измерения и отображают конечному пользователю как в виде суммарной информации со всех станций, так и по каждой станции в сети отдельно.

В этом проекте мы используем онлайн-платформу myDevices Cayenne для визуализации данных, полученных с сенсорных узлов [7]. Эта платформа позволяет пользователям собирать данные с помощью платформы The Things Network визуально привлекательным образом через веб-сайты или бесплатные мобильные приложения, которые можно загрузить в Apple Store или Google Play Store.

\section{Вывод}

В ходе выполнения данного исследования были проанализированы современные технологии в области сбора, передачи и обработки данных. Был сделан обзор стандартов организации сетей передачи данных, и дана оценка их применимости в сфере экологического мониторинга. Результатом проведённой работы стал проект расширяемой платформы мониторинга состояния окружающей среды.

Описанные в данной статье тезисы показывают, что как концепция «Интернета вещей» в целом, так и реализующие эту концепцию технологии могут найти широкое применение в области отслеживания состояния экологии. Их использование приведет к созданию систем мониторинга окружающей среды нового поколения, имеющих большое количество измерительных узлов, и при этом обладающих низкой стоимостью развертывания и обслуживания. Повсеместное внедрение данных решений позволит повысить интенсивность сбора данных, что положительно скажется на их точности и достоверности, так как станет возможным отслеживание динамики изменения состояния окружающей среды. Собранные и накопленные таким образом данные могут использоваться в качестве одного из источников информации при построении различных аналитических сервисов, ориентированных как на массового пользователя, желающего узнать о текущем состоянии экологии в месте своего проживания, так и на администрацию городов и поселков, имеющих возможность влиять на объем и характер вредных выбросов с предприятий, находящихся в их зоне ответственности.

\section{ЛИТЕРАТУРА}

1. Об охране окружающей среды [Электронный ресурс]: Федеральный закон от 10.01.2002 N 7-Ф3 (ред. от 29.07.2017). - Режим доступа: Система «Консультант Плюс».

2. Станции автоматического контроля загрязнения атмосферного воздуха АСКЗА-1 [Электронный ресурс]. - Режим доступа: http://www.td-str.ru/file.aspx?id=33135. - Заглавие с экрана. - (Дата обращения: 20.02.2020).

3. Четвертая парадигма [Текст] / ред. А. Хей, С. Тансли, К. Толле. - Редмонд: Microsoft Research, 2014-281 c.

4. Hart, J.K. Toward an environmental Internet of Things / J.K. Hart, K. Martinez // Earth and Space Science. - 2015. - №2. - P. 194-200.

5. LoRa Alliance [Электронный ресурс]. - Режим доступа: https://www.lora-alliance.org/. Заглавие с экрана. - (Дата обращения: 15.01.2020).

6. Курнасов Е.В. Оценка степени межуровневого взаимодействия информационных потоков производственного предприятия с MES-системой // Сборка в машиностроении и приборостроении. - 2012. - № 3. - С. 3-5.

7. myDevices Cayenne [Электронный pecypc]. - Режим доступа: https://mydevices.com/ Заглавие с экрана. - (Дата обращения: 30.01.2020).

$\overline{\text { International Journal of Information and Communication Technologies, Vol.1, Issue 1, March, } 2020}$ 
Данабекова М.Б., Сағынтай Г.Е.

Ғылыми жетекші: Айтмагамбетов А.З.

Қоршаған орта мониторингінің экологиялық платформасы

Андатпа. Бұл мақалада Arduino құрылғыларына негізделген сымсыз сенсорлық түйіндерден тұратын IoT платформасын, сенсорлық тораптарға желілік қосылысты қамтамасыз ететін Raspberry Pi шлюзін және деректерді жинауға және оны Интернет арқылы түпкі пайдаланушыға көрнекілендіруге қолданылатын желілік қосымшаларды құру әдісі ұсынылған. интерфейс немесе мобильді қосымша.

Кілт сөздер: LPWAN технологиясы, LoRaWAN, Arduino, Raspberry Pi.

Danabekova M.B., Sagyntay G.E.

Scientific superviser: Aitmagambetov A.Z.

Environmental platform for monitoring the environment

Abstract. This article presents a way to create an IoT platform consisting of wireless sensor nodes based on Arduino devices, a Raspberry Pi gateway that provides network connectivity for sensor nodes, and network applications that are used to collect data and visualize it to the end user via the web interface or mobile application.

Key words LPWAN technology, LoRaWAN, LoRa Alliance, ISM 868 МГц.

Сведения об авторах:

Сағынтай Г.Е., магистрант первого курса специальности «Телекоммуникации» Международного университета информационных технологий.

Данабекова М.Б., магистрант второго курса специальность «Телекоммуникации» Международного университета информационных технологий.

Айтмагамбетов Алтай Зуфарович, к.т.н., профессор кафедры «Радиотехника, электроника и телекоммуникации» Международного университета информационных технологий.

УДК 621.382.

Жаксылыков А.М.

Международный университет информационных технологий

Алматы, Казахстан

Научный руководитель: Даирбаев А.М-М.

\section{ИССЛЕДОВАНИЕ ЦИФРОВЫХ ТРАНСПОРТНЫХ СЕТЕЙ СВЯЗИ}

Аннотация. В статье представлено исследование иифровых транспортных сетей связи, основы планирования циирровых транспортных сетей связи и разработка топологии ичифровых транспортных сетей связи.

Ключевые слова: волоконно-оптические линии связи (ВОЛС), волновое мультиплексирование, пропускная способность, интегральная оптика.

Непрерывно возрастающие потребности общества в высокоскоростных и надежных системах передачи информации обусловили разработку и создание волоконно-оптических линий связи (ВОЛС) и развитие методов оптической обработки и передачи информации на основе новейших достижений оптоэлектроники, волоконной и интегральной оптики. Интегральная оптика призвана сыграть ту же роль по отношению к элементной базе 